\title{
ATHLETIC TECHNICAL SKILLS OF STUDENTS AS TRAINING EFFICIENCY INDICATOR
}

\author{
Sergey Barantsev ${ }^{1,2 \mathrm{ABCDE}}$, Elena Naidyonova ${ }^{1 \mathrm{ABCD}}$, Vera Serygina $^{1 \mathrm{ABCD}}$, Irina Merkulova ${ }^{1 \mathrm{ABCD}}$, \\ Vladimir Myshyakov ${ }^{3 \mathrm{ABCD}}$ \\ ${ }^{1}$ The State University of Management \\ ${ }^{2}$ Institute of Age Physiology of the Russian Academy of Education \\ ${ }^{3}$ Yanka Kupala State University of Grodno \\ Authors' Contribution: A - Study design; B - Data collection; C - Statistical analysis; D - Manuscript Preparation; E - Funds Collection
}

Corresponding Author: Sergey Barantsev, E-mail: barancev_sergei@mail.ru

Accepted for Publication: September 20, 2020

Published: September 25, 2020

DOI: 10.17309/tmfv.2020.3.04

\begin{abstract}
The purpose of the study is to evaluate the effectiveness of training sessions among the 1st-3rd year students of the general physical training (GPT) volleyball groups.

Materials and methods. The athletic technical skills (ATS) have been tested by results of tests on upper and lower passes and serves. ATS testing of students from GPT volleyball groups was carried out at the beginning and at the end of the spring semester, in which 45 of the 1st year students ( 2 study groups), 60 of the 2 nd year students ( 3 groups), 33 of the 3 rd year students (2 groups) took part. The same students took part in the testing at the beginning and at the end of the semester (pairwise comparison).

Research result. The method to evaluate the effectiveness of practical training for the Program of "Physical Culture" has been developed. Special aspects of ATS indicators dynamics of the 1st-3rd year students of GPT educational groups with sports orientation (volleyball) from the beginning to the end of spring semester were revealed.

Conclusion. The highest efficiency of training sessions was observed among the 2 nd year students. It is characterized by an increase in the number of students who successfully passed the tests on upper and lower passes by $5 \%$, and $12 \%$, respectively. The number of students who successfully passed the tests on serves increased by $11 \%$, and a performance level grew from middle at the beginning of the semester to high at the end of the semester.

The lowest effectiveness of training sessions was observed among the 1st year students. The outcome indicator of volleyball basic training corresponds to medium level at the beginning and at the end of the spring semester. The change in the number of students who successfully passed the tests on upper passes $(-2 \%)$, lower passes $(-2 \%)$, and serves $(+2 \%)$ was insignificant from the beginning to the end of the semester.
\end{abstract}

Keywords: athletic and technical skills (ATS), general physical training (GPT), testing, training session's effectiveness.

\section{Introduction}

A literature review shows an increasing number of students who have a low level of physical education (Shilko, 2007; Martynyuk \& Vilyansky, 2015; Druz, Iermakov, Nosko, Shesterova, \& Novitskaya, 2017). This affects the state of health, which is a factor in wellbeing of a future specialist (Korol, 2014; Kenioua \& Bowmased, 2016). The major reason is a sharp reduction in a physical activity (Grygiel-Górniak, Tomczak, Krulikowska, Przysławski, Seraszek-Jaros, \& Kaczmarek, 2016; Sternfeld, Gabriel, Jiang, Whitaker, Jacobs, Quesenberry, Carnethon, \& Sidney, 2019).

(C) Sergey Barantsev, Elena Naidyonova, Vera Serygina, Irina Merkulova, Vladimir Myshyakov, 2020.
The main problem in the university physical education management is a lack of information providing a feedback between subjects (Semenov \& Mironova, 2006; Anikieiev, 2015).

Assessment of a physical education state among students is a leading factor in the pedagogical process. It promotes a growth of athletic and technical skills of students (Sidorova, 2009) and contributes to increasing interest in a physical activity (Baka, 2010; Druz, Iermakov, Artemyeva, Puhach, \& Muszkieta, 2017).

The dynamics of physical fitness indicators cannot be a one objective criterion of a physical education effectiveness (Akhmatgatin, Lebedinsky, Khomyakov, Kudryavtsev, Galimova, Kamoza, Panov, Kuzmin, Gaskov, Sidorov, \& Doroshenko, 2020). 
Athletic and technical skills (ATS) are defined as one of indicators of a training sessions effectiveness among students from the Main Department (Shcherbakov, Volkov, \& Davidenko, 2010). It characterizes the level in the athletic technique. The need for the ATS assessment is noted by Ageevets, Efimov-Komarov, Efimova-Komarova, Lebedeva, and Perelman (2019), Ageevets, Efimov-Komarov, Efimova-Komarova, Nazarenko, and Puchkova (2020), Efimov-Komarova, Efimova-Komarova, Lebedeva, and Perelman (2020).

It is established that an athletic technique training increases the interest in practicing of a physical culture by students significantly (Sisova \& Semiglazova, 2015; Surikova \& Kozhanova, 2016; Bakuradze, 2020).

Tests to assess an athletic exercise technique in accordance with the athletic theory (Demchishin \& Pilipchuk, 1979; Zhelezniak, 1988; Zhelezniak \& Kunyansky, 2000; Sharafeeva, 2009) are widely used in a volleyball practice (Zatsiorsky, 1982; Godick, 1988).

Akhmerov, Akhmerov, and Shiryaev (2004) presented the results of theoretical and experimental studies that allow objectively characterize the testometric level of physical and theoretical fitness of volleyball players. Tests must meet two basic requirements: they must be reliable and informative.

The literature offers tests that are developed for qualified athletes, not suitable for non-athletes and do not have a sufficient bandwidth.

The literature review didn't identify any tests and standards to evaluate technical skills of volleyball players among students of non-sports universities (Scherbakov, et al., 2010).

There are following tests to assess volleyball technical fitness of beginner athletes (9-13 years old) of sports schools such as upper and lower passes, (above and in front, respectively), serve, attack and block (Pashkova, 2009; Gulyayeva, 2013).

There were tests developed to assess athletic and technical skills of the 1st through 3rd year students of general physical training groups (GPT) with a specialization in volleyball (Barantsev, Naidyonova, \& Sarycheva, 2009). Three tests were tested; they included upper/lower passes and serve. They became more complex from 1st through a 3 rd study year. It has been established that testing allows to objectively analyze a training level in volleyball playing basic technical skills among students of 1-3 study year and to evaluate athletic and technical fitness of GPT student groups.

The studies by Barantsev, Domashchenko, and Chicherin (2019), Barantsev (2020) presented tests and standards for assessing ATS among the GPT groups with various specializations (GPT-volleyball, GPT-football, GPT-basketball, GPTathletics, GPT-ping-pong, etc.).

Male and female 1st year students from the physical education groups, with a different sports specialization, showed significant differences in the development of general athletic fitness, both in the dynamics of average values and in comparing deviations (changes) in athletic fitness indicators from the beginning to the end of the school year. Female 1st year students from the GPT-aerobics group showed the highest level in a development of general physical fitness (6 points). In the GPT-athletics and GPT-volleyball groups the effectiveness is slightly lower (5 and 4 points, respectively). It corresponds to two points in the GPT athletics group (Grunina, Yermakov, Logacheva, \& Naidyonova, 2009). The development of basic physical skills during a "Physical Culture" practice reaches 5 points among young men of GPT-boxing group. The effectiveness is slightly lower among GTP-basketball group students (3 points). In the GPT-football groups, the effectiveness of classes is the lowest (1 point) (Barantsev, Kolesnikov, Pekhterev, \& Skorodumov, 2010).

We studied the dynamics and developed standards for assessing athletic and technical skills among the 1st year students of GPT-volleyball groups (Barantsev, Katilin, Naidyonova, \& Sarycheva, 2012). It was established that the use of the above tests in the educational process allows to objectively analyze a level of training among 1st and 2nd year students in basic technical methods of playing volleyball and to evaluate the athletic and technical skills of students of GPT- volleyball groups (Barantsev, Vedisheva, \& Naidyonova, 2013).

Barantsev and Naydenov (2017) presented a methodology and standards to assess an athletic and technical fitness among 1st-3rd year students of the GPT-volleyball groups.

It was established that the indicators of the athletic and technical skills decrease significantly from the 3 rd to 4 th semester among non-athletic students of the 2 nd study year from the GPT-volleyball groups. The reason is the decrease in the number of practical classes (from 40 in the 3 rd semester to 24 in the 4th semester) (Barantsev, Chicherin, Naidyonova, \& Bychkova, 2019).

The literature review didn't show any studies evaluating the effectiveness of practical classes based on indicators of athletic and technical skills among students from the GPTvolleyball groups.

The purpose of the study is to evaluate the effectiveness of training sessions among the 1st-3rd year students of the GPT-volleyball groups.

The objectives are:

1. To identify specifics of the test results among the 1st3rd year students from the GPT-volleyball groups during the spring semester.

2. Based on the ATS dynamics during a semester, evaluate the effectiveness of training sessions among the 1st-3rd year students from the GPT-volleyball groups.

\section{Materials and methods}

Table 1 summarizes tests we developed to evaluate ATS among 1st-3rd year students from the GPT-volleyball groups (Barantsev et al., 2009).

Detailed recommendations for testing are presented in the monograph (Barantsev et al., 2019) and the manual (Barantsev, 2020). The height of an upper and lower serve is $1.5-2.0 \mathrm{~m}$. A subject has three attempts to perform a test during one class. The test is performed a required number of times, non-stop. For each test, students get a "pass" or "failure" grade. Then, a study group training level is assessed for the first (test No. 1), second (test No. 2) and the third exercise (test No. 3).

Table 2 presents standards we developed to evaluate indicators of an athletic performance among GPT-volleyball groups (Barantsev \& Naydenova, 2017). The standards are the same for female and male students of the same study year.

Students who regularly attended practical classes and participated in testing were included into a study cohort as $100 \%$. A proportion of students who completed either upper or lower serve are considered $100 \%$.

Statistical analysis methods were employed to analyze the results. 
Table 1. Athletic and technical skills (ATS) tests evaluation of 1-3 courses students from GPT-volleyball groups

\begin{tabular}{|c|c|c|c|c|}
\hline \multirow{2}{*}{ № } & \multirow{2}{*}{ Test name } & \multicolumn{3}{|c|}{ Pass } \\
\hline & & 1 course & 2 course & 3 course \\
\hline 1 & $\begin{array}{l}\text { Upper pass with two } \\
\text { hands - above itself } \\
\text { (number of times) }\end{array}$ & $\begin{array}{l}15 \\
(\text { on area of } \\
\left.9 \times 9 \mathrm{~m}^{2}\right)\end{array}$ & $\begin{array}{l}20 \\
(\text { on area } \\
\left.\text { of } 9 \times 9 \mathrm{~m}^{2}\right)\end{array}$ & $\begin{array}{l}20 \\
\text { (on area } \\
\text { of } 3 \times 3 \mathrm{~m}^{2} \text { ) }\end{array}$ \\
\hline 2 & $\begin{array}{l}\text { Lower pass from } \\
\text { below with two } \\
\text { hands - in front } \\
\text { of you (number of } \\
\text { times) }\end{array}$ & $\begin{array}{l}15 \\
(\text { on area of } \\
\left.9 \times 9 \mathrm{~m}^{2}\right)\end{array}$ & $\begin{array}{l}20 \\
(\text { on area } \\
\left.\text { of } 9 \times 9 \mathrm{~m}^{2}\right)\end{array}$ & $\begin{array}{l}20 \\
(\text { on area of } \\
\left.3 \times 3 \mathrm{~m}^{2}\right)\end{array}$ \\
\hline 3 & $\begin{array}{l}\text { Serve (number of } \\
\text { times) optional: } \\
\text { - bottom (or side) } \\
\text { - from above }\end{array}$ & $\begin{array}{l}6 \text { of } 10 \\
5 \text { of } 10\end{array}$ & $\begin{array}{l}7 \text { of } 10 \\
6 \text { of } 10\end{array}$ & $\begin{array}{l}8 \text { of } 10 \\
7 \text { of } 10\end{array}$ \\
\hline
\end{tabular}

\section{Study design}

ATS testing of students from GPT-volleyball groups was carried out at the beginning and at the end of the spring semester, in which 45 of the 1st year students (2 study groups), 60 of the 2 nd year students (3 groups), 33 of the 3 rd year students ( 2 groups) took part. The same students took part in the testing at the beginning and at the end of the semester (pairwise comparison).

Students enrolled in study groups at the beginning of each semester at will. Therefore, their ability to play volleyball was different. In this regard, if a student did not play volleyball at all or took classes for just one semester, then he was tested according to the 1st study year program; if he took 2-3 semesters of classes then he was tested according to the 2 nd study year program; 4-5 semesters - according to the 3rd study year program.

The curriculum of the training sessions for students of the GPT-volleyball groups is presented in the manual (Barantsev, 2015). Students in these groups are mainly engaged in a general physical training and improving volleyball skills. A practical training methodology is based on a modern knowledge about volleyball playing technical skills among the 1st-3rd study year students from the GPT-volleyball groups (Zheleznyk, 1989; Sharafeeva, 2009).

There were 24 practical trainings conducted with the 1st, 2nd, 3rd study year students from the Main Department during a spring semester. Students neither from the Specialized department (students who had health problems) nor from the Sports Department (students who have a sports qualification and regularly participate in student sports competitions such as Moscow student games) didn't participate in the study. Health wise, all study participants belong to the core medical group.

\section{Study results}

Based on the test results, the teacher of the study group determines a proportion of students who pass the testing. Results are compared with the standards for assessing ATS indicators (Table 2).

Table 3 presents the dynamics of ATS indicators of the 1st, 2nd and 3rd study year students during a spring semester. A column on the left shows an academic semester and num-
Table 2. Athletic and technical skills (ATS) testing of students from general physical training group with sports orientation (volleyball)

\begin{tabular}{|c|c|c|c|c|c|}
\hline ن & $\begin{array}{c}\text { Level } \\
\text { ATS }\end{array}$ & $\begin{array}{c}\text { Upper } \\
\text { pass } \\
(\%)\end{array}$ & $\begin{array}{l}\text { Lower } \\
\text { pass } \\
(\%)\end{array}$ & $\begin{array}{c}\text { Serve } \\
\text { (top or } \\
\text { bottom } \\
-\% \text { ) } \\
\end{array}$ & $\begin{array}{c}\text { Assessment } \\
\text { of total level } \\
\text { ATS }\end{array}$ \\
\hline \multirow{3}{*}{1} & High & more 96 & more 93 & more 98 & more 96 \\
\hline & Medium & $85-96$ & $80-93$ & $88-98$ & $82-96$ \\
\hline & Low & less 85 & less 80 & less 88 & less 82 \\
\hline \multirow{3}{*}{2} & High & more 97 & more 94 & more 98 & more 96 \\
\hline & Medium & $82-97$ & $76-94$ & $85-98$ & $82-96$ \\
\hline & Low & less 82 & less 76 & less 85 & less 82 \\
\hline \multirow{3}{*}{3} & High & more 96 & more 93 & more 99 & more 95 \\
\hline & Medium & $82-96$ & $76-93$ & $86-99$ & $83-95$ \\
\hline & Low & less 82 & less 76 & less 86 & less 83 \\
\hline
\end{tabular}

ber of students in a study group who participated in the testing. The middle column represents a percentage of students who completed the test and reached a passing grade. The right column summarizes a final average test result for three tests.

Two groups of the 1st year students were tested in a spring semester. The trends in average performance indicators among 1st year students from the GPT-volleyball groups are presented in Figure 1.

The outcome indicator for students who completed upper and lower passes for a "pass" decreased by 2 percent, but still remained at the average level for training of these technical skills. The number of students who passed the testing increased by $2 \%$. At the same time, a number of students performing upper pass increased by $7 \%$ (Table 3 ), which is indicating the effectiveness of the volleyball technique training among 1st year students.

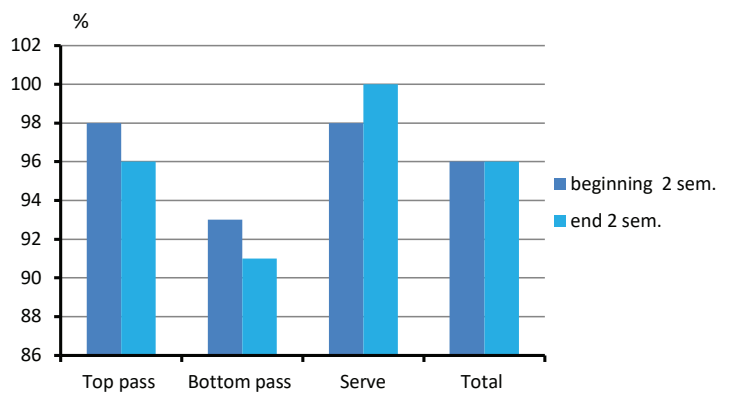

Fig. 1. Trends in average performance indicators of the 1st year students from GPT-volleyball groups

Three 2 nd year groups of students were tested at the beginning and at the end of a spring semester. The Figure 2 depicts trends in performance indicators of the 2 nd year students from GPT-volleyball groups.

The upper pass training rate increased by $5 \%$, the lower one - by $12 \%$ and remained at the medium level of training for both. The number of students who passed the testing increased by $11 \%$. The levels of these skills were medium at the beginning of the semester, and became higher at the 
Table 3. Dynamics of ATS indicators (\%) of students of 1-3 years academic group GPT-volleyball

\begin{tabular}{|c|c|c|c|c|c|c|}
\hline \multirow{2}{*}{ Semester, number of students } & \multirow{2}{*}{ Top pass } & \multirow{2}{*}{ Bottom pass } & \multicolumn{3}{|c|}{ Serve } & \multirow{2}{*}{ Total } \\
\hline & & & Total & Bottom & Upper & \\
\hline beginning 2 sem., $n=26$ & $96\left(m^{\star}\right)$ & $96(\mathrm{~h})$ & $96(\mathrm{~m})$ & 27 & 73 & $96(\mathrm{~m})$ \\
\hline end 2 sem., $n=26$ & $92(\mathrm{~m})$ & $92(\mathrm{~m})$ & $100(\mathrm{~h})$ & 25 & 75 & $95(\mathrm{~m})$ \\
\hline beginning 2 sem., $\mathrm{n}=19$ & $100(\mathrm{~h})$ & $89(\mathrm{~m})$ & $100(\mathrm{~h})$ & 35 & 65 & $96(\mathrm{~m})$ \\
\hline end 2 sem., $n=19$ & $100(\mathrm{~h})$ & $89(\mathrm{~m})$ & $100(\mathrm{~h})$ & 24 & 76 & $96(\mathrm{~m})$ \\
\hline \multirow{2}{*}{$\begin{array}{l}\text { Total: beginning } \\
2 \text { sem. } \quad \text { end }\end{array}$} & $98(\mathrm{~m})$ & $93(\mathrm{~m})$ & $98(\mathrm{~m})$ & 31 & 69 & $96(\mathrm{~m})$ \\
\hline & $96(\mathrm{~m})$ & $91(\mathrm{~m})$ & $100(\mathrm{~h})$ & 24 & 76 & $96(\mathrm{~m})$ \\
\hline beginning 4 sem., $n=22$ & $95(\mathrm{~m})$ & $95(\mathrm{~h})$ & $95(\mathrm{~m})$ & 25 & 75 & $95(\mathrm{~m})$ \\
\hline end 4 sem., $n=22$ & $100(\mathrm{~h})$ & $100(\mathrm{~h})$ & $100(\mathrm{~h})$ & 24 & 76 & $100(\mathrm{~h})$ \\
\hline beginning 4 sem., $\mathrm{n}=16$ & $75(1)$ & $75(1)$ & $93(\mathrm{~m})$ & 36 & 64 & $81(\mathrm{l})$ \\
\hline end 4 sem., $n=16$ & $75(1)$ & $94(\mathrm{~m})$ & $100(\mathrm{~h})$ & 33 & 67 & $90(\mathrm{~m})$ \\
\hline beginning 4 sem., $\mathrm{n}=22$ & $82(\mathrm{~m})$ & $73(1)$ & $79(1)$ & 16 & 84 & $78(\mathrm{l})$ \\
\hline end 4 sem., $\mathrm{n}=22$ & $91(\mathrm{~m})$ & $86(\mathrm{~m})$ & $100(\mathrm{~h})$ & 25 & 75 & $92(\mathrm{~h})$ \\
\hline \multirow{2}{*}{$\begin{array}{l}\text { Total : beginning } \\
4 \text { sem. } \quad \text { end }\end{array}$} & $84(\mathrm{~m})$ & $81(\mathrm{~m})$ & $89(\mathrm{~m})$ & 26 & 74 & $85(\mathrm{~m})$ \\
\hline & $89(\mathrm{~m})$ & $93(\mathrm{~m})$ & $100(\mathrm{~h})$ & 27 & 73 & $94(\mathrm{~m})$ \\
\hline beginning 6 sem., $n=22$ & $100(\mathrm{~h})$ & $76(\mathrm{~m})$ & $96(\mathrm{~m})$ & 24 & 76 & $91(\mathrm{~m})$ \\
\hline end 6 sem., $n=22$ & $95(\mathrm{~h})$ & $91(\mathrm{~h})$ & $100(\mathrm{~h})$ & 23 & 77 & $95(\mathrm{~h})$ \\
\hline beginning 6 sem., $n=11$ & $80(\mathrm{~m})$ & $73(\mathrm{~m})$ & $73(1)$ & 38 & 62 & $75(1)$ \\
\hline eEnd 6 sem., $n=11$ & $80(\mathrm{~m})$ & $82(\mathrm{~m})$ & $73(1)$ & 38 & 62 & $78(1)$ \\
\hline \multirow{2}{*}{$\begin{array}{l}\text { Total : beginning } \\
6 \text { sem. end }\end{array}$} & $90(\mathrm{~m})$ & $75(1)$ & $85(\mathrm{~m})$ & 31 & 69 & $83(\mathrm{~m})$ \\
\hline & $88(\mathrm{~m})$ & $87(\mathrm{~m})$ & $87(\mathrm{~m})$ & 31 & 69 & $87(\mathrm{~m})$ \\
\hline
\end{tabular}

* In a parentheses is an assessment of testing results among GPT students of each academic group - high (letter "h"), medium - "m" and

low - "l" (Table 2).

end of the semester. The outcome indicator for three tests increased by $9 \%$, but remained at the medium level. The following proves a high efficiency of training sessions with the 2nd year students.

Two 3rd year student groups were tested at the beginning and at the end of the spring semester. Trends in performance

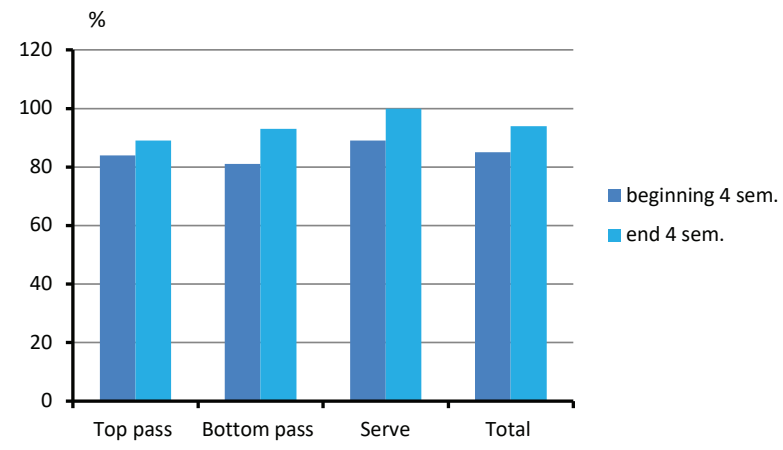

Fig. 2. Trends in performance indicators of the 2 nd year students from GPT-volleyball groups

indicators of the 3rd year students from GPT-volleyball groups are presented in Figure 3.

The number of students who passed the test on upper pass decreased by $2 \%$, but remained at medium level. Those ones who passed the test on lower pass and serve increased by $12 \%$ and $2 \%$, respectively. Although, this number remained at the medium level of training in these technical skills. The outcome indicator of training in three volleyball playing

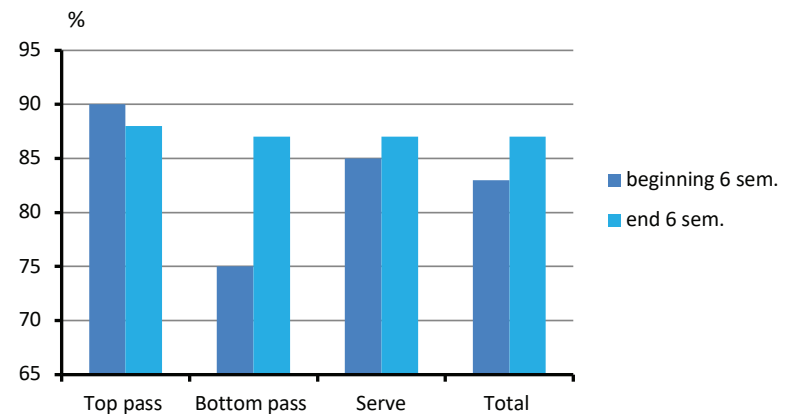

Fig. 3. Trends in performance indicators of the 3rd year students from GPT-volleyball groups

technical methods increased by $4 \%$. Therefore, 3 rd year students showed an improvement in the lower pass performing technique, and stabilizing in the upper pass and serves performing techniques during the semester. The outcome indicator of training in three volleyball technical methods remains at the medium level.

\section{Discussion}

The article presents the method to evaluate the effectiveness of practical training for the Program of "Physical Culture". It is based on the ATS indicators among 1st-3rd year students from the GPT-volleyball groups. It proposes the following:

- testing of volleyball basic techniques among students at the beginning and at the end of the semester; 
- generalization of test results by study groups and study year;

- determining the percentage of students who successfully passed tests;

- determining the outcome test indicators of study groups by a study year;

- evaluation of test results of study groups according to developed standards;

- analysis of trends in ATS among students by a study year.

This methodology is designed for physical culture coaches. Therefore the simplified statistical analysis such as a percentage and average calculation is used to evaluate test results. The proportion of students who successfully passed tests is compared with the ATS assessment standards. This methodology is simple and it is widely used in our practice.

The study results showed that reliable differences correspond to the ATS indicators change among students from GPT-volleyball groups by 7\% or more (Barantsev et al., 2019). Moreover, a high efficiency volleyball technical training is determined by moving from a lower to a higher level of training.

For example, the number of the 2 nd year students who successfully passed tests increased by $11 \%$. At the same time, the level of training has increased from medium at the beginning of the semester to high at the end of the semester. The most efficient training sessions for the 2 nd year students are characterized by a $12 \%$ increase in the number of students who successfully passed lower passes. In this case, the result at the end of the semester is only $1 \%$ less than the top boundary of medium level.

Similar trends in performance of lower passes are seen among 3rd year students - low level of training at the beginning of the semester reached medium one by the end of the semester. The performance increased by $12 \%$.

In one of 1st year training groups, the test results of upper and lower passes decreased by $4 \%$ but the test results of serves increased by $4 \%$. This case shows downward trend in a technical skills development and an improvement in serve performance.

Study groups are formed according to student interests. The attendance, student commitment during trainings differs. Therefore, instructor's performance during a semester should be evaluated according to average outcome indicators.

The study results showed that the assessment of training effectiveness is the most accurate when the same students from the GPT-volleyball groups are tested at the beginning and at the end of the semester. The ATS testing at the end of a semester only, characterizes the effectiveness of practical classes less accurately. This is negatively affected by a long winter session, exams, and a winter break; as well as students enrollment to specific groups at will in the beginning of each semester. Additionally, student ATS testing at the end of the semester only, does not allow to evaluate trends in testing indicators in the fall semester.

The standards we developed to evaluate ATS of the 1st3rd year students have three levels: high, medium and low level of training in basic volleyball techniques. Currently, statistical material to develop standards with additional educational levels is being compiled.

\section{Conclusion}

ATS testing results are one of the objective indicators to evaluate the effectiveness of practical classes and improve- ment of technical skills among the 1st-3rd year students from GPT-volleyball groups;

The highest efficiency of training sessions was observed among the 2 nd year students. It is characterized by an increase in a number of students who successfully passed the test on upper and lower passes by $5 \%$, and $12 \%$, respectively. The number of students who successfully passed the test on serves increased by $11 \%$, and a performance level grew from medium at the beginning of the semester to a high at the end of the semester.

Less effective training sessions were observed among $3 \mathrm{rd}$ year students. It is characterized by a $12 \%$ increase in a number of students who successfully passed the test on lower passes, and maintaining the same percentage of students who completed successfully passed the test on upper passes and serves. The outcome indicator of a training in three volleyball technical skills corresponded to medium level;

The lowest effectiveness of training sessions was observed among 1st year students. The outcome indicator of volleyball basic training corresponds to medium level at the beginning and at the end of the spring semester. The change in a number of students who successfully passed the test on upper passes $(-2 \%)$, lower passes $(-2 \%)$, and serves $(+2 \%)$ was insignificant from the beginning to the end of the semester.

\section{Conflict of interest}

Authors claim no conflict of interest.

\section{References}

Shilko, V.G. (2007). Organization of Athletic Training of Students in Classical University with Use of Sports and Health-Improving Technologies. Theory and practice of physical culture, 3, 2-6. https://elibrary.ru/item.asp?id=15415293

Martynyuk, O.V., \& Vilyanskiy, V.N. (2015). Assessment of students' health condition by indicators of adaptation potential, biological age and bio-energetic reserves of organism. Physical education of students, 19(3), 20-28. http://doi.org/10.15561/20755279.2015.0303

Druz, V., Iermakov, S., Nosko, M., Shesterova, L., \& Novitskaya, N. (2017). The problems of students' physical training individualization. Pedagogics, psychology, medicalbiological problems of physical training and sports, 21(2), 51-59. https://doi.org/10.15561/18189172.2017.0201

Korol, S.A. (2014). Assessment of physical health and physical fitness of students of technical specialties of I course. Pedagogics, psychology, medical-biological problems of physical training and sports, 18(11), 23-29. https://doi.org/10.15561/18189172.2014.1105

Kenioua, M., \& Bowmased, A. E. (2016). Sports and mental health among students in higher education. Physical education of students, 20(3), 39-42. https://doi.org/10.15561/20755279.2016.0305

Grygiel-Górniak, B., Tomczak, A., Krulikowska, N., Przysławski, J., Seraszek-Jaros, A., \& Kaczmarek, E. (2016). Physical activity, nutritional status, and dietary habits of students of a medical university. Sport Sciences for Health, 12(2), 261-267. https://doi.org/10.1007/s11332-016-0285-x

Sternfeld, B., Gabriel, K. P., Jiang, S.-F., Whitaker, K. M., Jacobs, D. R. J., Quesenberry, C. P. J., Carnethon, M., \& Sidney, S. (2019). Risk Estimates for Diabetes and Hypertension 
with Different Physical Activity Methods. Medicine \& Science in Sports \& Exercise, 51(12), 2498-2505. https://doi.org/10.1249/MSS.0000000000002083

Semenov, L.A., \& Mironova, S.P. (2006). "Student Physical Preparation Passport" as a means of feedback in the process of managing physical education in the university. Theory and Practice of Physical Culture, 5, 46-48. https://elibrary.ru/item.asp?id=14346906

Anikieiev, D. (2015). Criteria of effectiveness of students' physical education system in higher educational establishments. Physical Education of Students, 19(5), 3-8. https://doi.org/10.15561/20755279.2015.0501

Sidorova, T. V. (2009). An estimation of physical preparedness of students is 1-2 years. Pedagogy, psychology and medical and biological problems of physical education and sports, 12, 166-168. https://elibrary.ru/item.asp?id=12987481

Baka, R. (2010). Physical preparedness as reflection of formed of physical culture of students. Physical education of students, 2, 14-17. https://elibrary.ru/item.asp?id=13946828

Druz, V., Iermakov, S., Artemyeva, G., Puhach, Y., \& Muszkieta, R. (2017). Individualization factors of students' physical education at modern stage of its realization. Physical Education of Students, 21(1), 10-16. https://doi.org/10.15561/20755279.2017.0102

Akhmatgatin, A., Lebedinsky, V., Khomyakov, G., Kudryavtsev, M., Galimova, A., Kamoza, T., Panov, E., Kuzmin, V., Gaskov, A., Sidorov, L., \& Doroshenko, S. (2020). The effectiveness of students' preparation in physical training at the universities of various departments. Physical education of students, 24(1), 4-10. https://doi.org/10.15561/20755279.2020.0101

Scherbakov, V. G., Volkov, V. Yu., \& Davidenko, D. N. (2010). Example program of discipline "Physical culture". M., 12 p. http://siurgtu.ru/fgos_oop/progr/ppd_fiz.pdf

Ageevets, A.V., Efimov-Komarov, V.Y., Efimov-Komarov, L.B., Lebedeva, L.F., \& Perelman, M.B. (2019). Modern order of disciplines of physical culture and sports implementation in accordance with changes of the Federal Educational Standard. Scientific-theoretical journal Uchenye zapiski universiteta imeni P.F. Lesgafta, 1(167), 11-17. https://www.elibrary.ru/item.asp?id=36922475

Ageevets, A.V., Efimov-Komarov, V.Y., Efimova-Komarova, L.B., Nazarenko, E.A., \& Puchkova, M.V. (2020). On balance of requirements of the Federal State Educational Standard of Higher Education of the generation " $3++$ " to the discipline "Physical culture" of valid procedure for its implementation at the present stage. Scientific-theoretical journal Uchenye zapiski universiteta imeni P.F. Lesgafta, 1(179), 3-9. https://www.elibrary.ru/item.asp?id=42424770

Efimov-Komarov, V. U., Efimov-Komarova, L.B., Lebedev, L.F., \& Perelman, M.B. (2020). Problems and ways of implementation of elective disciplines on physical culture and sports in the university. Scientists of notes of university named after P.F. Lesgaft, 1(179), 125-131.

https://www.elibrary.ru/item.asp?id=42424799

Sisova, N.V., \& Semiglazova, E.P. (2015). Formation of motivation of students to engage in physical culture and sports. Prospects for the development of science in the field of pedagogy and psychology: collection of scientific works following the results of the international scientific and practical conference. Publishing house: Tolyattin State
University. Tolyatti, 35-39.

https://www.elibrary.ru/item.asp?id=23742496

Surikov, A.A., \& Kozhanov, V.I. (2016). Research on students interest and motivation in physical education. News of TULGU. Physical culture. Sport. Publishing house: Tula State University (Tula), 1, 119-125.

https://www.elibrary.ru/item.asp?id=26185929

Demchishin, A.A., \& Pilipchuk, B.S. (1979). Training of volleyball players. Kiev: "Health", $104 \mathrm{p}$.

Zhelezniak, U.D (1988). Young volleyball player: tutorial for trainers. M.: Physical culture and sport, $192 \mathrm{p}$. https://search.rsl.ru/ru/record/01001429047

Zhelezniak, U.D., \& Kunyansky, V.A. (2000). Volleyball: at the origin of skill. M.: Grandee, 323 p. https://search.rsl.ru/ru/record/01000576148

Sharafeeva, A.B. (2009). Training and improvement of the technique of playing volleyball: a methodological manual. Tomsk, 85 p. https://docplayer.ru/28277645-Obuchenie-isovershenstvovanie-tehniki-igry-v-voleybol.html

Zatsiorsky, V.M. (1982). Bases of the theory of tests. Sports metrology: textbook for institutes of physical culture. M.: FIS, 63-81. https://search.rsl.ru/ru/record/01001094379

Godik, M.A. (1988). Sports metrology: textbook for institutes of physical culture. M.: FiS, 192 p. https://spblib.ru/catalog/-/ books/3337711-sportivnaa-metrologia

Akhmerov, E.K., Akhmerov, V.E., \& Shiryaev, I.A. (2004). Pedagogical control over special physical and technical preparation of athletes in educational and training process on volleyball and tennis: methodological recommendations. Minsk, $59 \mathrm{p}$.

Bakuradze, N.S. (2020). Influence of physical education process on formation of reflection in university students. University Complex as a regional center of education, science and culture [electronic resource]: materials of the All-Russian Scientific and Methodological Conference; Orenburg state un-t. Orenburg: Regional public institution, 2831-2835. https://conference.osu.ru/archive/publications. html? detailed $=16$

Pashkova, N.V. (2009). Improvement of the methodology of education of children of 9-11 years of age with motor actions in volleyball. Avtoref., 30 p. https://search.rsl.ru/ru/ record/01003490841

Gulyaeva, G.U. (2013). Importance of control in training process of volleyball players. Tyumen, $18 \mathrm{p}$.

Barantsev, S.A., Naidyonova, E.G., \& Sarycheva, N.N. (2009). Planning of educational material and the basis of training in volleyball: educational and methodological manual for students of all specialties. Moscow: GUU, 55 p. https://www.elibrary.ru/item.asp?id=20099166

Barantsev, S.A., Domaschenko, V.S., \& Chicherin, V.P. (2019). General physical and sports and technical preparation of students: monograph. Moscow: RUSINES, $62 \mathrm{p}$. https://www.elibrary.ru/item.asp?id=41362137

Barantsev, S.A. (2020). Indicators of the effectiveness of physical education of students: a tutorial. Moscow: Soviet sport, 161 p. https://rucont.ru/efd/713602

Barantsev, S.A., Kolesnikov, E.N., Pekhterev, S.V., \& Skorodumov, M.A. (2010). Evaluation of the effectiveness of training sessions with students of the main department of OFP groups with different sports orientation. Almanac "New Studies". M.: Verdana, 3(24), 97-105. https://www.elibrary.ru/item.asp?id=17069570 
Barantsev, S.A., Vedisheva, T.A., \& Naidyonova, E.G. (2013). Evaluation of efficiency of practical classes of discipline "Physical culture" of female students 1 and 2 courses of the main department of OFP groups with sports direction (volleyball). Materials of the All-Russian with the international participation of the electronic student scientific conference. Irkutsk: FSBOU NI IrGTU, Vol. 1, 327-333. https://www.elibrary.ru/item.asp?id=25578694

Barantsev, S.A., Chicherin, V.P., Naidyonova, E.G., \& Bychkova, N.S. (2019). Peculiarities of dynamics of indicators of sports and technical preparation of students of 1-3 courses of the main department of OFP-volleyball groups. Sports Science Bulletin, 3, 50-53. https://elibrary.ru/item.asp?id=39196448

Barantsev, S.A., \& Naidyonov, E.G. (2017). Sports and technical training of students of 1-3 courses of the main department of OFP-volleyball groups. XXVII International Scientific and Practical Conference on Physical Education of Students "Person, Health, Physical Culture and Sports in a Changing World" [electronic annex]. Kolomna: MGOSGI, 309-314. https://chelovek-kolomna.ru/download.html
Barantsev, S.A. (2015). Planning of the content of training sessions of the discipline "Physical culture": educational and methodological manual. M.: GUU FGBOUVPO publishing house, $112 \mathrm{p}$. https://search.rsl.ru/ru/record/01007968357

Barantsev, S.A., Katilin, N.S., Naidyonova, E.G., \& Sarycheva, N.N. (2012). Sports and technical training of female students of the first year of the main department of OFP groups with sports direction (volleyball). Works of the 13 International Scientific Conference "Civilization of Knowledge: Problems and Prospects of Social Communications." M.: RosNOU, Ch.1. 94-96. https://www.elibrary.ru/item.asp?id=21007925

Grunina, I.V., Ermakov, A.D., Logacheva, V.V., \& Naidyonova, E.G. (2009). Methodology of evaluation of effectiveness of training sessions of CRF groups with different sports direction. Materials of the All-Russian Scientific and Practical Conference "Theory and Practice of Physical Culture and Sports in Conditions of Modernization of Education," Izhevsk, 164-166. https://www.elibrary.ru/item.asp?id=19402797

\title{
СПОРТИВНО-ТЕХНІЧНА ПІДГОТОВЛЕНІСТЬ СТУДЕНТІВ ЯК ІНДИКАТОР ЕФЕКТИВНОСТІ ПРАКТИЧНИХ ЗАНЯТЬ
}

\author{
Сергій Баранцев ${ }^{1,2 \mathrm{ABCDE}}$, Олена Найдьонова ${ }^{1 \mathrm{ABCD}}$, Вiра Серьогіна $^{1 \mathrm{ABCD}}$, \\ Iрина Меркулова $^{1 \mathrm{ABCD}}$, Володимир Миш'яков ${ }^{3 \mathrm{ABCD}}$ \\ ${ }^{1}$ Державний університет управління \\ ${ }^{2}$ Інститут вікової фізіології Російської академії освіти \\ ${ }^{3}$ Гродненський державний університет імені Янки Купали
}

\begin{abstract}
Авторський вклад: А - дизайн дослідження; В - збір даних; C - статаналіз; D - підготовка рукопису; Е - збір коштів
Реферат. Стаття: 7 с., 3 табл., 3 рис., 39 джерел
\end{abstract}

Мета дослідження - оцінити ефективність навчально-тренувальних занять зі студентами 1-3 курсів основного відділення навчальних груп загальної фізичної підготовки (ОФП) зі спортивною спрямованістю (волейбол).

Матеріали і методи. Спортивно-технічну підготовленість (СТП) студентів навчальних груп ОФП-волейбол оцінювали за результатами тестування верхньої, нижньої передачі та подачі. Тестування СТП студентів навчальних груп ОФП-волейбол проводили на початку та наприкінці весняного семестру, в якому взяли участь 45 студентів 1 курсу (2 навчальні групи), 60 студентів 2 курсу (3 групи), 33 студенти 3 курсу (2 групи). У тестуванні брали участь одні й ті ж студенти (попарно-зв'язкові варіанти).

Результати. Розроблено технологію оцінки ефективності практичних занять дисципліни «Фізична культура» на підставі одного з індикаторів - спортивно-технічної підготовленості студентів 1-3 курсів навчальних груп ОФП-волейбол. Виявлено особливості динаміки показників СТП студентів 1-3 курсів навчальних груп
ОФП зі спортивною спрямованістю (волейбол) від початку до кінця весняного семестру.

Висновок. Найбільш висока ефективність навчально-тренувальних занять відзначена на 2 курсі. Вона характеризується збільшенням кількості студентів які здали на «залік» верхні і нижні передачі на 5\% і 12\% відповідно. Кількість студентів, які виконали на «залік» подачі, збільшилася на $11 \%$, а рівень навченості 3 середнього на початку семестру виріс до високого в кінці семестру. Порівняно нижча ефективність навчальнотренувальних занять виявлена на 1 курсі. Підсумковий показник навченості студентів 1 курсу основним прийомам гри у волейбол на початку і в кінці весняного семестру відповідає середньому рівню. Динаміка кількості студентів, які виконали на «залік» верхні передачі (-2\%), нижні передачі (-2\%), подачі (+2\%), від початку до кінця семестру незначна.

Ключові слова: спортивно-технічна підготовленість, загальна фізична підготовка, тестування, ефективність практичних занять. 


\section{Information about the authors:}

Barantsev Sergey: barancev_sergei@mail.ru; https://orcid.org/0000-0002-7765-1755; Department of physical culture, The State University of Management, 109542 Moscow, Ryazansky Prospect, 99, Russia. Laboratory of physiology of muscular activity and physical education, Institute of Age Physiology of the Russian Academy of Education, 119121 Moscow, Pogodinskaya St, 8, building 2, Russia.

Naidyonova Elena: naidenovalena@yandex.ru; https://orcid.org/0000-0003-1216-4689; Department of physical culture, The State University of Management, 109542 Moscow, Ryazansky Prospect 99, Russia.

Serygina Vera: sereginava@mail.ru; https://orcid.org/0000-0003-0674-3297; Department of physical culture, The State University of Management, 109542 Moscow, Ryazansky Prospect, 99, Russia.

Merkulova Irina: irene.merkulova@yandex.ru; https://orcid.org/0000-0003-2409-2117; Department of physical culture, The State University of Management, 109542 Moscow, Ryazansky Prospect, 99, Russia.

Myshyakov Vladimir: vmyshakov@mail.ru; https://orcid.org/0000-0002-1555-4853; Department of sports disciplines, School of physical culture, Yanka Kupala State University of Grodno, Ozheshko St, 22, Grodno, Belarus.

Cite this article as: Barantsev, S., Naidyonova, E., Serygina, V., Merkulova, I., \& Myshyakov, V. (2020). Athletic Technical Skills of Students as Training Efficiency Indicator. Teoriâ ta Metodika Fizičnogo Vihovannâ, 20(3), 149-155. https://doi.org/10.17309/tmfv.2020.3.04

Received: 12.06.2020. Accepted: 20.09.2020. Published: 25.09.2020

This work is licensed under a Creative Commons Attribution 4.0 International License (http://creativecommons.org/licenses/by/4.0). 